\title{
【奨励賞研究】
}

\section{覚醒下脳腫瘍摘出術におけるリアルタイム 手術工程同定システム}

\author{
永井 智大 \\ 公立はこだて未来大学大学院 システム情報科学研究科 システム情報科学専攻
}

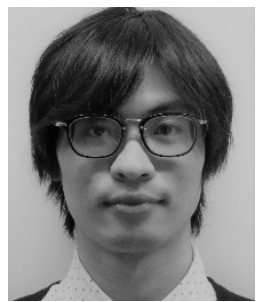

\section{1. はじめに}

覚醒下脳腫瘍摘出術において, 執刀医は患者ごとの発話や運動 機能といった脳機能局在を把握することで脳機能の損傷を抑え, 腫 瘍を限りなく摘出する.一方で, 脳機能の損傷を抑えた摘出より手術 が複雑化し, 若手医師や手術スタッフが手術の流れを把握し予測す ることが難しい. そこで本研究では, 術中にて若手医師や手術スタッ フがリアルタイムに手術の流れを把握可能とする手術工程同定シス テムを開発する. 本システムは, 手術工程が複雑化する覚醒下脸腫 瘍摘出術を対象とし, 手術室内にある複数の医療機器加の情報を 用いて手術工程を少アルタイムに同定する. 本システムを評価するた め, 手術工程同定精度および速度計測を実施する。

\section{2. 覚醒下脳腫場摘出術用手術工程モデルの構築}

手術工程を同定するため, 覚醒下脳腫場摘出術の手術工程モデ ルを構築する. 本研究では, 脳の開頭後から腫瘍摘出が完了寸るま での一連の手術工程の流れをモデル化する. モデルは過去の臨床 データを用いて臨床医の意見にもとづいて定義する. そのため, 10 症例を対象に MRI, 手術ナビゲーションシステムログ(以下, ナビロ グ)および手術顕微鏡動画を用いて臨床医の意見より 12 個の手術工 程を定義し, 3 階層の手術工程モデルを構築した. 1 階層は 3 クラス (腫瘍摘出前処置, 腫瘍摘出中, アイドリング)に分類する. 2 階層は 4 クラス(摘出前準備, 術中診断, 腫瘍摘出, 脳機能検査)を分類する. 3 階層は定義した 12 工程を 2 階層の子要素しして分類し, 各手術工 程の遷移関係を構成寸る. 以上より, 覚醒下脳腫瘍摘出術における 3 階層の手術工程モデルを構築する.

\section{3. 機械学習を用いたリアルタイム手術工程同定}

本システムは, 複数の医療機器から得られる情報から機械学習に より手術工程の特徴となる情報を少アルタイムに取得し同定する. 本 研究で使用する情報は, MRI, ナビログおよび手術顕微鏡動画であ る. 手術工程同定は, 以下の 3 ステップで行う. STEP1: 脳構造上で の処置位置の取得, STEP2: 使用する術具の種類の取得, STEP3: 取得結果を用いた手術工程の同定. 手術工程同定の流孔をFig. 1 に 示寸. STEP1 では, ナビログと MRI から画像処理によって, 脳構造 上の処置位置 (腫瘍内部, 脳表, 正常脳, 脳領域外)を取得する.
STEP2 では, 手術顕微鏡動画からあらかじめ学習した YOLO (You Only Look Once)を用いて動画上に映る 3 つの術具 (バイポーラ, 電 気刺激プローブ, 剪刀)を検出する. STEP3 では, STEP1, 2 で取得 した情報から手術工程モデルにもとづいて HHMM (Hierarchical Hidden Markov Model)を用いて階層ごとに手術工程を同定する. 同 定処理は 1 秒毎に行い, リアルタイムに手術工程の同定を行う.

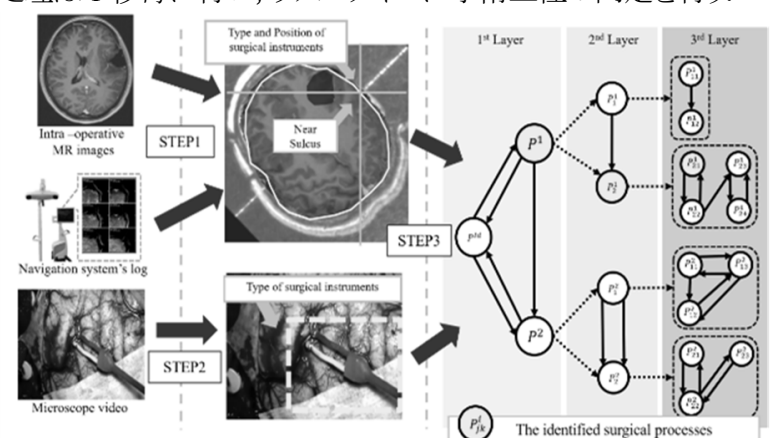

Fig. 1 Method for Surgical Process Identification

\section{4. 精度評価実験および処理速度計測}

本手法による手術工程同定の有用性を確認するため, 過去に取得 した臨床データを用いて精度評価実験と処理速度の計測を行った。 評価方法として, 本システムを用いた自動工程同定結果と手動で作 成した正解同定結果を比較し, 精度を算出した. また, 処理速度計 測 は PC(CPU: Core i7-6700K, RAM: 32GB, GPU: GeForce GTX1080Ti)を使用し, 1 秒毎の結果を出力に要する処理時間を算 出した. 手術工程同定結果は, 第 1 階層(3クラス)は $96.6 \%$, 第 2 階 層(4クラス)は $96.5 \%$ となった. そして, 第3 階層(12 工程)は $95.3 \%$ の 精度結果となった. また, 処理時間は, $39.6 \pm 8.43$ ミ秒( 1 秒毎)の処 理時間を要し, 1 秒以内に同定結果を算出することが可能となった.

\section{5. 精度評価実験および処理速度計測}

本研究では, 覚醒下脳腫瘍摘出術における複数の医療機器情報 を用いた機械学習による手術工程同定システムを開発した. 本シス テムの評価実験結果より, 手術工程を高精度で同定し,リアルタイム 性を担保した形で情報を呈示可能であることを示した. 手術工程同 定精度の低下として, ログの欠損や機械学習による誤検出が挙げら れる. 今後は, 機械学習の精度向上を行うとともに, 手術工程同定結 果を解析し, 執刀医の手技の可視化を目指寸. 本研究開発は総務 省 SCOPE(162101001)の委託を受けたものである. 